\title{
Optimalisasi Peran Santriwati Melalui Departemen Kebersihan Dalam Menciptakan \\ Kebersihan Pondok Dimasa Pandemi Covid-19 Di Pondok Pesantren Hudatul Muna 2 \\ Ponorogo
}

\author{
Siti Maulidah \\ Pengembangan Masyarakat Islam(PMI), Fakultas Dakwah INSURI Ponorogo \\ nengmaulidalbumen@gmail.com
}

\begin{abstract}
Based on the results of the organizational assistance of the cottage hygiene department in optimizing the cleanliness of the role of students in creating cleanliness of the cottage using the ABCD (Asset based Community Development) approach, the success of mentoring is determined by the activeness of the stakeholders. Companions will not be able to do without students who play an active role. So that with the active role of students, the cleanliness of the cottage and is better maintained. This is because it is driven by programs planned by the cottage hygiene department in optimizing the role of students in maintaining the cleanliness of the cottage environment.
\end{abstract}

Keywords: Role, Students And Cleanliness.

Abstrak: Berdasarkan hasil pendampingan organisasi departemen kebersihan pondok dalam mengoptimalisasikan kebersihan peran santri dalam menciptakan kebersihan pondok dengan menggunakan pendekatan ABCD (Asset based Community Development) maka keberhasilan pendampingan ditentukan oleh keaktifan para stake holder. Pendamping tidak akan mampu berbuat tanpa adanya santri yang berperan aktif. Sehingga dengan adanya peran santri yang aktif tersebut kebersihan pondokdan terjaga lebih baik. Hal ini karena didorong oleh program-program yang direncanakan oleh departemen kebersihan pondok dalam mengoptimalisasi peran santri dalam menjaga kebersihan lingkungan pondok.

Kata kunci: Peran, Santri Dan Kebersihan.

\section{A. Latar Belakang}

Kabupaten ponorogo adalah sebuah kabupaten di Provinsi Jawa Timu Indonesia. Kabupaten ini terletak di koordinat $111^{\circ} 17^{\prime}-111^{\circ} 52^{\prime}$ BT dan $7^{\circ} 4^{\prime} 9^{\prime}-8^{\circ} 20^{\prime}$ LS dengan ketinggian antara 92 sampai dengan 2.563 meter di atas permukaan laut dan memiliki luas wilayah $1.371,78 \mathrm{~km}^{2}$ yang dibagi menjadi 2 sub-area yaitu dataran tinggi yang meliputi kecamatan Ngrayun, Sooko, Pulung, dan Ngebel dan sisanya merupakan area dataran rendah. Kabupaten ini terletak di bagian barat provinsi jawa timur dan terbatas langsung dengan provinsi jawa tengah atau lebih tepatnya $220 \mathrm{~km}$ arah barat daya dari ibu kota provinsi jawa timur, Surabaya. Kabupaten Ponorogo dikenal dengan julukan Kota Reog atau Bumi Reog karena daerah ini merupakan asal dari kesenian Reog, Ponorogo juga dikenal sebagai Kota Santri karena memiliki banyak pondok pesantren.Kabupaten ponorogo terdiri dari 21 
kecamatan, 26 kelurahan, dan 281 desa (dari total 666 kecamatan, 777 kelurahan, dan 7.724 desa di jawa timur).

Indonesia pada umumnya adalah suatu negara yang menganut agama Islam, lebih dari 80 persen wilayah Indonesia di huni oleh orang-orang islam. Islam mengajarkan kepada para pemeluknya untuk selalu menjaga kesehatan dan kebersihan lingkungan dalam kehidupan karna kebersihan merupakan sebagian dari iman.Dalam kehidupan bernegara, masyarakat berkewajiban menjaga kebersihan lingkungan. Berdasarkan Undang -Undang Lingkungan hidup nomor 4 tahun 1982 tentang pengelolaan lingkungan hidup yang berdefenisi lingkungan hidup adalah kesatuan ruang dengan semua benda, daya, keadaan dan makhluk hidup termasuk manusia dan perilakunya yang mempengaruhi alam itu sendiri, kelangsungan perkembangan dan kesejahteraan manusia serta makhluk hidup lainnya (Soemartono2003). Lingkungan hidup merupakan faktor utama dalam kehidupan, semua lapisan masyarakat dan pemerintah berkewajiban untuk menjaga kebersihan lingkungan dan kesejahteraan bagi manusia. Lingkungan itu meliputi halaman pekarangan, rumah, jalan, dan lingkungan sekitar, segala sesuatu yang terjadi di lingkungan akan berpengaruh terhadap kelangsungan kesejahteraan manusia dan makhluk hidup lainnya.( Wikipedia,2012). Lingkungan adalah upaya perlindungan, pengelolaan dan modifikasi lingkungan yang di arahkan menuju keseimbangan ekologi pada tingkat kesejahteraan manusia yang semakin meningkat.Kontribusi lingkungan dalam mewujudkan derajat kesehatan merupakan hal yang esensial di samping masalah perilaku masyarakat, pelayanan kesahatan. Lingkungan memberikan kontribusi terhadap timbulnyamasalah kesehatan masyarakat, lingkungan pada dasarnya merupakan usaha untuk mengelola semua faktor yang ada pada lingkungan yang berkaitan dengan perkembangan fisik dan kesehatan sedemikian rupa sehingga kesehatan dapat di tingkatkan yang salah satunya melalui cara yaitu dengan menjaga kebersihan lingkungan. (Supardi dalam Efrida 2011).

Lingkungan adalah suatu sistem komplek yang berada di individu yang mempengaruhi pertumbuhan dan perkembangan makhluk hidup.Usaha perbaikan lingkungan dan perubahan tingkah laku merupakan usaha yang efesien dan efektif untuk meningkatkan derajat kesehatan. Adapun untuk mencapai lingkungan yang bersih dan sehat adalah dengan menyediakan berbagai fasilitas penunjang kebersihan seperti penyediaan air bersih, wc yang baik, kamar mandi, tempat pembuangansampah serta tempat penyaluran air limbah (Ade Efrida 2011).Dalam kehidupan sehari hari manusia tidak terlepas dari keterkaitannya pada lingkungan seperti udara, air yang menjadi bagian dari lingkungan hidup yang perlu di 
tingkatkan.Peningkatan kebersihan lingkungan hidup bertujuan untuk mencapai suatu keadaan terkendali dalam lingkungan hidup yang seimbang dengandinamika pertumbuhan hidup dalam menunjang terwujudnya derajat kesehatan dan kesejahteraan yang optimal serta terwujudnya manusia Indonesia sebagai insan lingkungan hidup yang memiliki sikap dan tindakan melindungi serta membina dan memelihara lingkungan hidup yang bisa menghindari penyebab kerusakan lingkungan.

Saat ini, kehidupan di pondok pesantren menjadi sangat rentan terhadap penularan kasus Covid-19, mengingat jumlah santri yang sangat banyak di satu lokasi. Bila satu orang menderita Covid-19 maka penularanya akan sangat cepat, Sebenarnya tidak hanya Covid-19 yang menjadi ancaman bagi kesehatan para santri akan tetapi juga dari kebersihan Lingkungan setempat, "Ujar Dr Atik Nurwahyuni, salah seorang anggota tim pengamdian masyarakat (pengmas) Fakultas Kesehatan Masyarakat Universitas Indonesia (FKM UI) yang memberikan pendampingan peningkatan hidup bersih sehat bagi para santri di pondok pesantren.Saat ini perilaku hidup bersih sudah diterapkan oleh para santri.Santri sudah terbiasa membersihkan lingkungan pondok pesantren, membakar sampah dipenampungan sampah, membersihkan kamar mandi agar air tidak menyebabkan tersumbatnya air selokan, membersihkan asrama pondok, dan mematuhi protocol kesehatan dari Pemerintah.Diharapkan perilaku hidup bersih dan sehat ini tetap melekat pada diri santriwan dan santriwati walaupun pandemic berakhir sehingga santri juga terhindar dari penyakitpenyakit yang umumnya sering menular pada santri seperti diare, gatal-gatal, muntaber dan lain-lain.Pondok Pesantren Hudatul Muna 2, di mana program pengabdian ini dilaksanakan, yang berada diwilayah perkotaan dan sebelahan dengan sungai yang sangat kental dengan kondisi lingkungan yang memperhatikan. Sampah bertebaran di mana-mana, sungai yang mengalami pendangkalan karena sampah.Sebagai lembaga yang berada di perkotaan maka pondok pesantren Hudatul Muna 2menjadi gambaran mikro dari kondisi bersebelahan dengan sungai.Kondisi kebersihan dan ketrampilan di dalam pondok pesantren yang sangat tampak, dalam pemakaian plastic yang tinggi, kurang terbiasanya menggunakan peralatan yang bertahan lama, tempat sampah yang kurang memadai, serta santri-santri yang kurangnya menjaga kebersihan lingkungan. Dengan pertimbangan bahwa pondok pesantren Hudatul Muna 2 berada di lingkungan perkotaan yang kondisinya sangat diperhatikan oleh orangorang sekitar maka harus terjaganya kebersihan lingkungan setempat dan penanaman pola hidup bersih dengan pengelolahan sampah yang baik akan berdampak pada kehidupan diri, dan komunitas yang lebih baik. 
Berdasarkan deskripsi diatas maka diperlukan penelitian lebih lanjut untuk mengoptimalisasikan peran santriwati melalui menjaga kebersihan lingkungan pada masa pandemic covid-19. Melalui pendekatan ABCD (Asset based Community Development) memungkinkan peneilitian serta pengurus dan santri bekerja sama dalam menggalih assetasset yang berada di Kelurahan Brotonegaran Pondok Pesantren Hudatul Muna 2 Ponorogo dan mengoptimalisasikan asset tersebut, yang dimulai dari sosialisasi mengenali asset, merencanakan, dan mengevaluasi program guna untuk kemajuan dan meningkatkan santriwati dalam menjaga kebersihan lingkungan pondok pesantren.

\section{B. Metode Pengabdian}

Pendampingan ini menggunakan pendekatan Asset Based Community Development $(\mathrm{ABCD})$, yang mengutamakan pemanfaatan aset dan potensi yang ada disekitar dan di miliki oleh masyarakat.Untuk kemudian digunakan sebagai bahan yang memberdayakan masyarakat itu sendiri. Pendekatan berbasis asset memasukan cara pandang baru yang lebih holistic dan kreatif dalam melihat realitas, seperti melihat gelas setengah penuh mengaprresiasikan apa yang bekerja dengan baik dimasa lampau dan menggunakan apa yang kita miliki untuk mendapatkan apa yang kita inginkan (Christopher Dureau, 2013). Pendekatan ini lebih memilih cara pandang bahwasannya dalam ponok pesantren pasti memiliki sesuatu yang dapat di berdayakan maupun di manfaatkan, karena selalu ada manfaat yang dapat diambil dari setiap ciptaan Tuhan. Aset sendiri merupakan suatu hal yang dapat digunakan atau dimanfaatkan guna memenuhi kebutuhan dan bernilai kekayaan.

Pendekatan berbasis aset membantu komunitas kenyataan seseorang dan kemungkinan perubahan secara berbeda. Mempromosikan perubahan focus pada apa yang ingin mereka capai dan membantu mereka menemukan cara baru dan kreatif untuk mewujudkan visi mereka. Pondok Pesantren merupakan asset yang paling berharga bagi seluruh santri yang berada di dalam pondok pesantren, Sebagaimana Kebersihan Lingkungan Pondok Pesantren adalah asset yang sangat berharga dimana santri harus menjaga kebersihan Lingkungan Pondok Pesantren yang jauh dari pandangan orang tua agar bias menjaga kekebalan tubuh santri dan tidak menghawatirkan kedua orang tua di Kelurahan Brotonegaran khususnya di Pondok Pesantren Hudatul Muna 2 dan seluruh Pondok Pesantren di Ponorogo pada Umumnya.

Dalam Metode ABCD memiliki lima langkah kunci untuk melakukan proses riset pendampingan di antaranya : (Charistopher Dureau, 2013). 
1. Discovery (Menemukan)

Proses menemukan kembali kesuksesan dilakukan lewat proses percakapan atau wawancara dan harus menjadi penemuan personal tentang apa yang menjadi kontribusi individu yang memberi hidup pada sebuah kegiatan atau usaha. Pada tahap Discovery, kita mulai memindahkan tanggung jawab untuk perubahan kepada para individu yang berkepentingan dengan perubahan tersebut yaitu entitas local. Dengan langgah ini pendampingan melakukan sosialisasi kepada seluruh santri di pondok pesantren Hudatul Muna 2 tentang pentingnya menjaga bersihan lingkungan yang bias dijadikan asset.

2. Dream (Impian)

Pada tahap ini, setiap orang mengeksplorasi harapan dan impian mereka baik untuk diri mereka sendiri, lingkungan pondok pesantren maupun untuk organisasi.Santri atau salah satu pengurus pondok pesantren di Hudatul Muna 2 setelah di wawancarai olehpendampingan maka diajak untuk menggambarkan mimpi-mimpi yang belum tercapai.

\section{Design (Merancang)}

Pada tahap ini, orang atau komunitas mulai merumuskan strategi. Proses dan sistem membuat keputusan dan mengembangkan kolaborasi yang mendukung terwujudnya perubahan yang diharapkan. Dalam proses ini pondok pesantren merancang asset lingkungan yang di miliki untuk dimanfaatkan sebagai langkah meningkatkan kebersihan lingkungan dipondok pesantren dimasa pandemic.

4. Define (Menentukan)

Kelompok pemimpin sebaiknya menentukan "pilihan topic positif" : tujuan dari proses pencarian atau deskripsi mengenai perubahan yang di inginkan. Langkah selanjutnya adalah menentukan kegiatan positif yang dilakukan oleh para santri di pondok pesantren Hudatul Muna 2 yakni optimalisasi peran santri dalam pemanfatan asset.

\section{Destiy(Lakukan)}

Serangkaian tindakan inspiratif yang mendukung proses belajar terus menerus dan inovasi tentang "apa yang akan terjadi." Hal ini merupakan fase akhir yang secara khusus focus pada cara-cara personal dan organisasi untuk melangkah maju. Langkah yang terakhir adalah melakukan kegiatan yang sudah disepakati untuk memenuhi impian santri dan pengurus dari pemanfaatan asset. 
Dalam pendampingan masyarakat dengan metode $\mathrm{ABCD}$, ada beberapa prinsip yang harus diperhatikan. Adapun prinsipnya adalah sebagai berikut : (Nadhir Salahuddin, 2015)

1. Setengah Terisi Lebih Berarti (Half Full Half Empty)

Modal utama dalam program pengabdian terhadap masyarkat berbasis aset adalah merubah cara pandang komunikasi terhadap dirinya. Tidak hanya terpaku pada kekurangan dan masalah yang di miliki. Tetapi memberikan perhatian kepada apa yang dipunyai dan apa yang dapat dilakukan.

2. Semua Punya Potensi (Nobody Has Nothing)

Dalam konteks ABCD, prinsip ini dikenal degan istilah “Nobody Has Nothing”. Setiap manusia terlahir dengan kelebihan masing-masing.Tidak ada yang tidak memiliki potensi, walau hanya sekedar kemampuan untuk tersenyum dan merebus mie instan.Semua berpotensi dansemua bias berkontribusi.

\section{Partisipasi (Participation)}

Partisipasi ialah suatu keterlibatan mental dan emosi seseorang kepada pencapaian tujuan dan ikut bertanggung jawab di dalamnya.Partisipasi berarti peran yang sangat urgen terhadap lingkungan pondok pesantren untuk meningkatkan santri menjaga bersihan lingkungan dimasa pandemic dalam bentuk pernyataan maupun dalam bentuk kegiatan dengan memberi masukan pikiran, tenagan, waktu, keahlian, serta ikut memanfatkan hasil-hasilnya.

\section{Kemitraan (Partnership)}

Merupakan salah satu prinsip utama dalam pendekatan pengembangan masyarakat berbasis aset $\mathrm{ABCD}$.Partnership merupakan modal utama yang sangat dibutuhkan dalam memaksimalkan posisi dan peran masyarakat dalam pengembangan yang dilakukan. Hal ini di maksudkan sebagai bentuk pembangunan dimana yang menjadi motor dan pengerak utamanya adalah masyarakat itu sendiri (Community Driven Development).

\section{Penyimpanan Positif (Positive Deviance)}

Positive Deviance atau PD secara harfiah berarti penyimpanan positif. Secara terminology positive deviance (PD) adalah sebuah pendekatan terhadap perubahan perilaku individu dan social yang di dasarkan pada realitas bahwa dalam setiap masyarakat meskipun bias jadi banyak terhadap orang-orang yang mempraktekkan strategi atau perilaku sukses yang tidak umum, yang memungkinkan mereka untuk 
mencapai solusi yanglebih baik atau masalah yang dihadapi daripada rekan-rekan mereka.

6. Berawal Dari Masyarakat (Endogenous)

Endogenous dalam konteks pembangunan memiliki beberapa konsep inti yang menjadi prinsip dalam pendekatan pengembangan dan pemberdayaan komunitas masyarakat berbasis asset kekuatan.

7. Menuju Sumber Energi (Heliotropic)

Energy dalam pengemangan bias beragam. Diantaranya adalah mimpi besar yang dimiliki olek komunitas, proses pengembangan yang apresiatif, atau bias juga keberpihak anggota komunitas yang penuh totalitas dalam pelaksanaan program.

\section{Hasil dan Pembahasaan}

\section{Peran Santri Melalui Organisasi Departemen Kebersihan Di Pondok Pesantren Hudatul Muna 2, Desa Brotonegaran, Kecamatan Ponorogo, Kabupaten}

\section{Ponorogo.}

Departemen Kebersihan adalah sebuah nama devisi atau bidang di dalam organisasi kepengurusan pondok yang ada di Pondok Pesantren Hudatul Muna 2 Ponorogo. Sejak mulai tahun 2020, karena kepengurusan ini berlaku dua tahun periode yakni 2020-2022.Maksud dan tujuan organisasi ini adalah sebagai wadah komunikasi para santri dalam meningkatkan kesadaran untuk menjaga kebersihan lingkungan di Pondok Pesantren.Sehingga dengan adanya organisasi ini mampu mendorong kesadaran para santri untuk meningkatkan kesadaran santri dalam menjaga kebersihan lingkungan Pondok Pesantren Hudatul Muna 2 Ponorogo. Organisasi saat ini di prakarsai oleh para santri yang berada di Pondok Pesantren Hudatul Muna 2 Ponorogo, sehingga nama yang diberikan adalah Departemen Pondok Pesantren.

Sebagaimana tujuan awal untuk komunikasi para santri dan pengurus dalam menciptakan kebersihan lingkungan Pondok Pesantren Hudatul Muna 2. Posisi saat ini ada suatu program kerja yang dicetuskan, tetapi dalam setengah periode ini program kerja yang dicetuskan tidak berjalan dengan maksimal, maka departemen kebersihan pondok mengevaluasi kendala-kendala yang menghambat dalam program kerja, setelah mengevaluasi program kerja yang tidak terlaksana maka departemen 
pondpk pesantren ini melakukan trobosan baru untuk memaksimalkan programprogram yang di ketuskan. Trobosannya yaitu :

1) Membuat virgo (kelompok) untuk para santri.

2) Memaksimalkan jadwal piket

3) Mengadakan sosialisasi tentang kebersihan kepada para santri

4) Memberikan sanksi kepada santri yang tidak melaksanakan piket.

Dari hasil evaluasi tersebut kemudian Departemen pondok memaksimalkan potensipotensi yang ada untuk kemudian digunakan sebagai pemberdayaan dalam menciptakan kebersihan lingkungan pondok pesantren.

Di dalam kamus umum Bahasa Indonesia, peran adalah sesuatu yang jadi bagian atau yang memegang pimpinan yang tertentu. Bias dijabarkan bahwa peran adalah sebuah kedudukan seseorang dalam tatanan masyarakat yang bisa mempengaruhi keadaan social. Peranan merupakan aspek dinamis dari kedudukan (status), Apabila seorang melakukan hak dan kewajiban sesuai dengan kedudukan, maka hal itu berarti seseorang menjalankan suatu peran. Keduanya tidak bias dipisahkan karena yang satu tergantung pada yang lain dan sekitarnya. Setiap orang mempunyai macam-macam peranan yang berasal dari pola-pola pergaulan hidupnya. Hal itu sekaligus berarti bahwa peran menentukan apa yang diperbuatnya bagi masyarakat serta kesempatan-kesempatan apa yang diberikan masyarakat kepadanya. Sementara dalam kajian sosiologi, psikologi dan antropologi istilah peran merupakan perpaduan berbagai teori, orientasi maupun disiplin ilmu.Istilah peran sendiri lebih diartikan pada kaitannya dalam dunia pentas atau drama. Teori peran berbicara tentang istilah "peran” yang biasa digunakan dalam dunia teater, dimana seorang actor dalam teater harus bermain tokoh tertentu dan dalam posisinya sebagai tokoh itu ia diharapkan untuk berperilaku secara terntu. Posisi seorang actor dalam teater dinalogika dengan posisi seorang dalam masyarakat, dan keduanya memiliki kesamaan posisi.

Peran diartikan pada karakterisasi yang disandang untuk dibawakan oleh seorang actor dalam sebuah pentas drama, yang dalam konteks social peran diartikan sebagai suatu fungsi yang dibawakan seseorang ketika menduduki suatu posisi dalam struktur social. peran actor adalah batasan yang dirancang oleh actor lain, yang 
kebetulan sama-sama berbeda dalam satu penampilan atau unjuk peran. (Wikipedia. Org/wiki/kebersihan.Diakses 2012)

Menciptakan kebersihan lingkungan pondok pesantren bagi para merupakan hal yang sangat penting untuk di laksanakan agar lingkungan pondok yang mereka tempati menjadi bersih, indah di pandang mata dan terhindar dari penyakit.Menciptakan kebersihan lingkungan pondok pesantren ialah kesadaran dari diri santri itu sendiri bukan karena hanya takut kepada pembina asrama.Sehingga dapat di terapkan dengan baik di lingkungan asrama tempat mereka tinggal, di samping hal itu perlu juga kebiasaan santri yang diwujudkan melalui perilaku serta tindakan yang nyata untuk menciptakan kebersihan lingkungan tersebut dalam diri santri. Karena apabila kebersihan lingkungan telah diciptakan, maka para santri yang tinggal di pondok pesantren akan selalu hidup sehat, terhindar dari penyakit dan merasa senang tinggal di lingkungan pondok pesantren secara bersama-sama. Dalam hal ini bahwa peran santriwati dalam menciptakan kebersihan lingkungan sangat-lah diperlukan untuk mencapai kehidupan yang sehat dan terhindar dari penyakit.

Salah satu kegiatan yang dilakukan santri dalam menjaga kebersihan lingkungan adalah memebersihkan halaman depan dan belakang pondok pesantren, membakar sampah di penampungan, mematuhi peraturan Pembina asrama dalam hal menjaga kebersihan lingkungan menyapu kamar serta membersihkan-nya. Adapun bentuk peran santri yang dilakukan dalam menjaga kebersihan lingkungan yaitu dengan cara sederhana yaitu dengan cara membersihkan halaman pondok pesantren depan maupun belakang akan tetapi tidak membuang sampah pada penampungannya dan tidak ada kesadaran untuk membakar smpah tersebut.

Didalam menjaga kebersihan lingkungan pondok pesantren juga dilakukan oleh departemen kebersihan dan dibantu oleh anggotanya dengan memberikan sangsi kepada santri dan mengadakan perlombaan kebersihan lingkungan sekitar diasrama ppondok pesantren Hudatul Muna 2walaupun hanya di adakan satu kali dalam satu semester.

2. Faktor Pendorong dan Penghambat Peran Santriwati Dalam Melalui Menciptakan Kebersihan Lingkungan Pondok Pesantren Di Hudatul Muna 2 Ponorogo 
Dalam menjaga Kebersihan Lingkungan Pondok Pesantren Hudatul Muna 2 terhadap pelaksanaan program peran santriwati dalam menjaga kebersihan lingkungan ini sangat ditentukan oleh beberapa faktot, Antara lain :

1) Factor Pendorong

Berbagai dukungan yang diberikan oleh Yayasan Pondok Pesantren Hudatul Muna 2, yakni menjaga kebersihan sangatlah perlu ditindak lanjuti untuk para santri yang pada dasarnya kurang kesadaran diri dalam hal pentingnya menjaga kebersihan lingkungan pondok pesantren.Selain sosialisasi yang dilakukan didepan para santriwati juga dilakukan, kerja nyata seperti membersihkan dan membakar sampah dipenampungan sampah.Adanya mengoptimalisasikan peran santri, merupakan salah satu factor yang dapat mendukung berkembangnya kebersihan lingkungan pondok pesantren di Hudatul Muna 2 Ponorogo.

Peran mahasiswa yang diberikan kepada santriwati membuat para santri menjadi disiplin dalam menjalankan piket sehari-hari di lingkungan pondok pesantren dan mendapat pengetahuan yang telah diberikan oleh salah satu mahasiswa KPM-DR. hal tersebut juga membantu pengurus dan para santri lainnya untuk mendapatkan hasil yang maksimal, dimana hasil yang maksimal tersebut juga mampu meningkatkan peran santri dalam menjaga kebersihan lingkungan pondok pesantren di Hudatul Muna 2 Ponorogo.

2) Factor Penghambat

Selain terdapat factor pendorong, peran santriwati untukmeningkatkan kebersihan didalam pondok pesantren ini juga terdapat factor penghambat, yaitu SDM yang kurang mempunyai pengetahuan pentingnya menjaga kebersihan didalam pondok pesantren. Akan tetapi para santri masih sama saja membuang sampah tidak pada tempatnya dan tidak segera membakar sampah dipenampungan sampah jika sudah penuh, sehingga menimbulkan penyakit dan kurangnya kebersihan lingkungan pondok.Selain itu factor cuaca juga sangat berpengaruh dalam menjaga kebersihan lingkungan setempat. Cuaca yang sangat sulit untuk diprediksi secara langsung akan berpengaruh terhadap kebersihan lingkungan pondok dan kesehatan para santri.

\section{Kesimpulan}


Berdasarkan hasil penelitian dan pembahasan dalam mengenai peran santri dalam mengoptimalisasikan kebersihan lingkungan pondok pesantren di Hudatul Muna 2 Ponorogo dapat disimpulkan sebagai berikut :

1. Peran santri dalam menciptakan kebersihan lingkungan pondok pesantren diartikan sebagai sesuatu yang harus dilaksanakan karena apabila santri telah menciptakan kebersihan lingkungan akan menjadi lingkungan menjadi sehat, terhindar dari penyakit, melalaui kegiatan-kegiatan yang dapat menciptakan lingkungan menjadi bersih, seperti gotong-royong, membuang sampah pada tempatnya yang telah disediakan, akan tetapi pengetahuan santri tentang menciptakan kebersihan tidak sesuai dengan perilaku mereka terhadap kebersihan lingkungan.

2. Peran santri dalam menjaga kebersihan lingkungan dilakukan dengan pembentukan firqoh-firqoh dengam membersihkan halaman lingkungan pondok pesantren depan maupun belakang, membakar sampah jika sudah penuh, membersihkan selokan, mematuhi dan menjalankan peraturan dari departemen kebersihan dipondok pesantren Hudatul Muna 2. Akan tetapi dalam menyikapi semua ini, para santri hanya melakukan dengan cara yang sederhana seperti membersihkan halaman akan tetapi tidak membuang sampah ditempat penampungan sampah dan tidak sekaligus dibakar, membersihkan kamar hanya dengan cara menyapu dan membuang sampah akan tetapi tidak membuang sampah di tempat penampungan sampah.

\section{E. Refrensi}

Anonimus. 2011. http:// Wikipedia. Org/ wiki/ kebersihan. Diakses 12 Desember 2012.

Setyono, Prabang. 2008. Cakrawala Memahami Lingkungan. Lembaga Pengembangan Pendidikan dan UNS Pres : Surakarta

Soemartono,P.Gatot 1996. Hukum Lingkungan Indonesia. Sinar Grafika : Jakarta

Soemirat, Juli. 2011. Kesehatan Lingkungan. Yogyakarta

Wahyuni. Novi 2010. Budaya Masyarakat Dalam Menjaga Kebersihan Lingkungan di Kelurahan Berok Nipah Kecamatan Padang Barat. Skripsi STKIP PGRI : Padang

https://adoc.pub/queue/peranan-santri-dalam-mengelola-kebersihan-lingkungan-asrama-.html 
JCD: Journal of Community Development and Disaster Management Vol 3 No 1 | Januari- Juni 2021 